\title{
Evaluation of Antidiabetic, Antioxidant and Other Phytochemical Properties of Thai Fruits, Vegetables and Some Local Food Plants
}

\author{
Suree NANASOMBAT ${ }^{*}$, Kanokwan YANSODTHEE and Ilada JONGJAITED
}

Department of Biology, Faculty of Science, King Mongkut's Institute of Technology Ladkrabang, Bangkok 10520, Thailand

('Corresponding author's e-mail: snanasombat@gmail.com)

Received: 3 April 2017, Revised: 18 February 2018, Accepted: 17 March 2018

\begin{abstract}
Antidiabetic, antioxidant, anti-acetylcholinesterase and prebiotic activities, total phenolics and flavonoids of 33 crude ethanolic extracts of Thai local fruits, vegetables and some local food plants were determined. Mangosteen (Garcinia mangostana) fruit peel and Indian gooseberry (Phyllanthus emblica) fruit extracts had highest antioxidant activity. Bamboo grass (Tiliacora triandra) leaf extract had strongest $\alpha$-amylase inhibitory activity (78.28 \% inhibition), while mulberry (Morus alba) fruit extract had strongest $\alpha$-glucosidase inhibitory activity (59.63\% inhibition). Star cactus (Aloe vera) leaf pulp extract had strongest anti-acetylcholinesterase activity (31.55\% inhibition). Indian gooseberry fruit and mangosteen fruit peel extracts had highest content of total phenolics and flavonoids, respectively. The extract with highest indigestible polysaccharide content was the extract of mangosteen fruit peels (188.62 $\mathrm{mg} / \mathrm{g}$ extract), while those with relatively high indigestible polysaccharides were the extracts of pineapple fruits (Ananas comosus), lotus seeds (Nelumbo nucifera), black rice grains (Oryza sativa) and pisang mas banana fruits (Musa sapientum). Based on these properties, 5 plant extracts were selected to study for their prebiotic effect on growth and fermentation of Lactobacillus acidophilus, Lactobacillus bulgaricus and Streptococcus thermophilus in yogurt at $42{ }^{\circ} \mathrm{C}$. Addition of lotus seed extract resulted in highest proliferation of these bacteria with $2.24 \log \mathrm{CFU} / \mathrm{g}$ increase of total lactic acid bacterial counts in yogurt after $24 \mathrm{~h}$ fermentation, while addition of black rice grain, pisang mas banana fruit and pineapple fruit extracts caused good growth of these bacteria with $2.12-2.19 \log \mathrm{CFU} / \mathrm{g}$ increase of total counts.
\end{abstract}

Keywords: Antidiabetic, antioxidant, anti-acetylcholinesterase, prebiotics, edible plants

\section{Introduction}

Fruits and vegetables are rich in many micronutrients including vitamins $\mathrm{C}$ and vitamin $\mathrm{A}$ and some electrolytes. They provides low calorie, and are good sources of phytochemicals functioning as antioxidants, phytoestrogens and anti-inflammatory compounds. More than 5,000 phytochemical compounds have been isolated from fruits, vegetables and cereals. Main phytochemical antioxidant compounds in foods that have been reported were i) polyphenols such as flavonoids (isoflavones, flavones, flavonols, anthocyanins, flavanols, and flavanones), phenolic acids, stilbenes and lignans, ii) glucosynolates and iii) carotenoids [1]. As beneficial effect of antioxidants on disease prevention is well known, there are an increase awareness on the role of nutrients on defence against oxidative stress and damages induced by free radicals. Oxidative stress is an imbalance between formation of reactive oxygen/nitrogen species and ability of organisms to fight against reaction occurred by using antioxidant system. Oxidative stress reduces ability of internal system to fight against targeted biological molecules. Excessive production of free radicals leads to damage to lipid, protein, carbohydrate, and DNA molecules. Damage induced by oxidative stress has been confirmed to be related to pathogenesis, pathophysiology of some chronic diseases affecting health problems $[1,2]$. Certain nutrients in food are 
http://wjst.wu.ac.th

important for prevention of oxidative stress injury or free radical induced diseases. There were evidences that intake of fruits and vegetables could reduce risk of oxidative stress related diseases such as diabetes, Alzheimer's disease and other diseases [3].

Diabetes mellitus is a common form of chronic metabolic disorder, characterized by disruptions in metabolism of carbohydrate, proteins and fat, and caused by defects of insulin secretion and/or insulin action. Among the 2 types of diabetes (type 1 and type 2 diabetes mellitus), type 2 diabetes mellitus (noninsulin dependent diabetes mellitus) is more common form and accounts for $90-95 \%$ of all diabetic cases. Most diabetes patients will eventually suffer from multiple complications including neuropathy, nephropathy, retinopathy, ketoacidosis, diabetic foot, heart attack, stroke and cardiovascular disease [4,5]. Decreasing post-prandial hyperglycemia is a therapeutic approach for treating diabetes in the early state. This is accomplished by retarding the absorption of glucose through the inhibition of carbohydratehydrolyzing enzymes such as $\alpha$-amylase and $\alpha$-glucosidase in the digestive tract. These enzyme inhibitors can delay carbohydrate digestion and prolong overall carbohydrate digestion time causing delayed glucose absorption rate. Some drugs such as biguanides, sulfonylureas, meglitinides, thiazolidinediones, $\alpha$-glucosidase inhibitors, incretinmimetics, dipeptityl peptidase-IV inhibitors and insulin have been used in control and treatment of diabetes. However, most of these drugs usually result in some severe side effects [5]. Therefore, use of plant derived drug is alternative way to treat diabetes. Several plants have been reported to possess anti-diabetic activity in experimental rat [5]. However, only few information regarding $\alpha$-amylase and $\alpha$-glucosidase inhibitory activity of Thai fruits and vegetables has been reported.

Alzheimer's disease (AD) is a neurodegenerative disease, the most common form of dementia among the elderly. This disease is characterized by progressive decline in memory which affects brain function, neuronal loss in regions associated with memory and cognition, as well as accumulation of extracellular $\beta$-amyloid and intraneuronal neurofibrillary tangles. AD affects important parts of brain as well as the cortex and limbic system [6]. In addition, AD patients' brains were found to loss acetylcholine which is an important neurotransmitter of central nervous system responsible for increased memory and enhanced learning. Acetylcholine is related to signal transport in synapse. After transporting signal in the synapse, it will be hydrolyzed to choline and acetate by enzymatic reaction. Use of acetylcholinesterase inhibitor is one strategy to treat this disease as it can protect the cells from free radical toxicity and injury induced by $\beta$-amyloid [7]. Some acetylcholinesterase inhibitors such as physostigmine and tacrine have been used for symptomatic treatment of $\mathrm{AD}$. Athough these drugs can obstruct the progress of $\mathrm{AD}$, there are some disadvantages. For example, physotigmine has weak activity against oral cavity, poor penetration to brain and pharmacokinetics, while tacrine has hepatotoxic [8]. Thus, there is the need to search for natural, safe and effective anti-Alzheimer's disease and anti-diabetic drug with antioxidant activity. The use of natural antioxidants plays an important role in prevention of oxidative stress related diseases. Some researches have used free radical scavengers from plants with glutathione containing antioxidants and substances with RH groups, vitamin, polyphenol and other compounds to decrease the effect of oxidative stress [9].

Thai herbs, fruits and vegetables are a major source of natural antioxidants such as polyphenol (phenolics, flavonoids), vitamin C and other compounds [10,11]. Some Thai local plants including fruits of Indian gooseberry (Phyllathus emblica) [11,12] and black rice (Oryza sativa) [13], fruit peels of mangosteen (Garcinia mangostana) [14], and leaves of lopea tree (Acanthopanax trifoliatus) [15] were reported to have very high phenolic content and strong antioxidant activity. So far, only few plants with strong anti-diabetic and anti-acetylcholinesterase activities have been reported [12,16-18]. For instance, Alium sativum (garlic) bulbs [19], Ginkgo biloba leaves [19], Terminalia chebula fruits [5], Aloe vera leaves and Morinda citrifolia barks/leaves [16] have good anti-diabetic effect, while Stephania pierrei tubers [18] and Nelumbo nucifera (lotus) petals [12] have strong anti-acetylcholinesterase activity. However, there are still many interesting Thai local plants that have never been investigated. Therefore, the search for new acetylcholinesterase, $\alpha$-amylase and $\alpha$-glucosidase inhibitors with strong antioxidant activity from natural sources is of great interest.

Fruits and vegetables not only provides phytochemicals for preventing chronic diseases, but they are good source of dietary fiber [10,11]. Dietary fiber includes non-digestible carbohydrates (resistant starch, 
http://wjst.wu.ac.th

resistant maltodextrins, fructo-oligosaccharides and galacto-oligosaccharides). These are prebiotics which are able to resist digestion in small intestine and then will be fermented in the large intestine [20]. Prebiotics not only stimulate the growth of probiotic bacteria, a beneficial natural flora, but improve function of intestine wall and host immune system [21]. Some plants such as banana, onion, garlic and Jerusalem artichoke (Helianthus tuberosus) have been reported to contain fructo-oligosaccharide and inulin. Inulin is a small molecule of fructo-oligosaccharide that plants store as a nutrient [22].

In the current study, 33 crude ethanolic extracts of fruits, vegetables and some Thai local food plants were screened for their antioxidant, antidiabetic and anti-acetylcholinesterase activities as well as their phenolic, flavonoid and indigestible polysaccharide contents for use to study the prebiotic property, a growth enhancement of probiotic bacteria in yogurt. The plants selected were the plants known to possess either one of those potential activities and the plants that have never or rarely been studied. The studied plants listed in Table 1 are Thai local edible plants widely consumed as fresh fruits and vegetables, spices and herbs, or used as ingredients in Thai traditional cuisine, especially seven interesting plants collecting from Chiang Mai in northern Thailand. These were lopea tree (A. trifoliatus), Pak Chiangda (Gymnema inodorum) and Pak huanmoo (Dregea volubilis) consumed as fresh vegetables or used as an ingredient for cooking Thai curry in northern Thailand, Malodge (Elaeagnus latifolia) consumed as fresh fruits and sometimes used to relieve constipation, local apple (Chrysophyllum cainito) consumed as fresh fruits, mulberry (Morus alba) consumed as raw or cooked fruits or used as an ingredient in mulberry wine making, and Jeekuk (Zingiber zerumbet, a tuberous root herb plant) wildly used in foods and beverages and used traditionally as herbal medicine for treatment of many aliments due to its potential biological and pharmacological properties [23].

\section{Materials and methods}

\section{Extraction of plant materials}

Thirty three species of fruit, vegetable and some local Thai food plants (Table 1) were used in this study. These plant materials were washed, cut, dried at $40{ }^{\circ} \mathrm{C}$, and ground to a fine powder. Then, $10 \mathrm{~g}$ of each were soaked in $100 \mathrm{~mL}$ of $80 \%$ ethanol, and shaken at $150 \mathrm{rpm}$ for $48 \mathrm{~h}$. The mixtures were filtered. The filtrates were evaporated using vacuum rotary evaporator and air dried at $40{ }^{\circ} \mathrm{C}$. Then, these dried extracts were ready for use to prepare the stock solution.

\section{$\alpha$-amylase inhibition assay}

Alpha-amylase inhibition assay was analyzed according to the method as described by Sancheti et al. [24] with little modification. Briefly, $240 \mu \mathrm{L}$ of $1 \%$ starch solution (Starch soluble, 14418, Sisco Research Laboratories Pvt. Ltd., India) was mixed with $120 \mu \mathrm{L}$ plant extract sample, and incubated at 37 ${ }^{\circ} \mathrm{C}$ for $5 \mathrm{~min}$. Then, $240 \mu \mathrm{L}$ of $\alpha$-amylase (from porcine pancreas, A6255, Sigma-Aldrich, USA) solution ( 1 unit $/ \mathrm{mL}$ in $0.5 \mathrm{M}$ Tris $\mathrm{HCl}$ buffer) was added into this mixture, and incubated at $37{ }^{\circ} \mathrm{C}$ for $3 \mathrm{~min}$, followed by addition of $240 \mu \mathrm{L}$ color reagent: the mixture of i) $12 \mathrm{~g}$ sodium potassium tartrate dissolved in $8 \mathrm{~mL}$ of $2 \mathrm{M} \mathrm{NaOH}$ and ii) $96 \mathrm{mM} \mathrm{3,5-dinitrosalicylic} \mathrm{acid} \mathrm{in} \mathrm{the} \mathrm{ratio} \mathrm{of} \mathrm{1:1,} \mathrm{Loizzo} \mathrm{et} \mathrm{al.} \mathrm{[25].} \mathrm{The}$ mixture was boiled in a water bath for $15 \mathrm{~min}$, cooled down to ambient temperature, and diluted by adding 2,160 $\mu \mathrm{L}$ distilled water. The absorbance of this reaction mixture was measured at $540 \mathrm{~nm}$ using UV-visible spectrophotometer (UV1601, Shimadzu Scientific Instruments (Oceania) Pty. Ltd., Australia). Acarbose solution (1 mg/mL) (A9890-1G, Sigma, China) was used as a positive control, while $30 \%$ ethanol was used as a negative control. The $\alpha$-amylase inhibitory activity was calculated using the following equation;

$\% \alpha$-amylase inhibition $=\frac{\text { A control }- \text { A sample }}{\text { A control }} \times 100$

where A control is the absorbance of control and A sample is the absorbance of sample. 
Table 1 Fruits, vegetables and some Thai local food plants used in this study.

\begin{tabular}{|c|c|c|c|}
\hline Scientific name & Thai name/ Common name & Family & Plant part \\
\hline Acanthopanax trifoliatus Merr. & Pak pam/Lopea tree & Araliaceae & Whole plant \\
\hline Alium sativum Linn. & Thai garlic/ Common garlic & Amaryllidaceae & Bulb \\
\hline Allium oschaninii & Hom Dang Thai/ Shallot & Amaryllidaceae & Bulb \\
\hline Aloe vera (Linn.) Burm.f. & Wan HangJarake/ Star Cactus & Aloaceae & Leaf pulp \\
\hline Ananas comosus (L.) Merr. & Subparos-sriracha/ Pineapple & Bromeliaceae & Fruit pulp \\
\hline Annona squamosa Linn. & Noina/ Sugar apple & Annonaceae & Fruit pulp \\
\hline Carissa carandas Linn. & Mamuanghow ma now ho/ Karunda & Apocynaceae & Fruit \\
\hline Centella asiatica Linn. Urban. & Buabok/ Asiatic pennywort & Apiaceae & Whole plant \\
\hline Chrysophyllum cainito Linn. & Local apple/ Star apple & Sapotaceae & Fruit \\
\hline Dregea volubilis Stapf. & Pak huan moo/ ${ }^{-a}$ & Asclepiadaceae & Flower \\
\hline Elaeagnus latifolia Linn. & Malodge/ Bastard Oleaster & Elaeagnaceae & Fruit \\
\hline Garcinia mangostana Linn. & Mungkut/ Mangosteen & Clusiaceae & Fruit peel \\
\hline Ginkgo biloba L. & Pagkuaw/ Maidenhair tree & Ginkgoaceae & Leaf \\
\hline Gymnema inodorum Lour. & Pak chiangda/ Gymnema & Asclepiadaceae & Whole plant \\
\hline Helianthus tuberosus Linn. & Kantawan/ Jerusalem artichoke & Asteraceae & Tuber \\
\hline Ipomoea batatas (L.) Lam. & Mantorpuek/ Purple sweet potato & Comvolvulaceae & Tuber \\
\hline Ipomoea batatas (L.)Lam. & Manted/ Orange Sweet potato & Comvolvulaceae & Tuber \\
\hline Malus domestica Borkh. & Appledang/ Red apple & Rosaceae & Fruit \\
\hline Morinda citrifolia Linn. & Yaw/Great morinda & Rubiaceae & Fruit \\
\hline Morus alba Linn. & Mon/ Mulberry & Moraceae & Fruit \\
\hline Momordica cochinchinensis (Lour.) Spreng. & Fugkawn/ Gac fruit & Cucurbitaceae & Fruit \\
\hline Musa sapientum Linn. (AA group) & Kluai Lep Mu Nang/ Lep Mu Nang banana & Musaceae & Fruit pulp \\
\hline Musa sapientum Linn. (AA Khai) & Kluai khai/ Pisang Mas banana & Musaceae & Fruit pulp \\
\hline Musa sapientum Linn.(Musa ABB cv. Kluai 'Namwa') & Kluai Namwa/ Cultivated banana & Musaceae & Fruit pulp \\
\hline Nelumbo nucifera Gaertn. & Medbua/ Lotus seed & Nelumbonaceae & Seed \\
\hline Oryza sativa & Kawdam/ Black rice & Poaceae & Fruit \\
\hline Passiflora laurifolia Linn. & Saowaros/ Passion fruit & Passifloraceae & Fruit pulp and seed \\
\hline Phyllanthus emblica Linn. & Makampom/ Indian gooseberry & Phyllanthaceae & Fruit \\
\hline Salacca zalacca (Gaerth.) Voss & Sara/ Salak plum & Arecaceae & Fruit pulp \\
\hline Tiliacora triandra (Colebr.) Diels & Yanang/ Bamboo grass & Menispermaceae & Leaf \\
\hline Zanthoxylum limonella Alston. & Maquand/ Kamchat ton & Rutaceae & Seed \\
\hline Zea mays Linn. var. saccharata & Kawpodwan/ Sweet corn & Poaceae & Seed \\
\hline Zingiber zerumbet (Linn) Smith. & Jeekuk/ Shampoo ginger & Zingiberaceae & Rhizome \\
\hline
\end{tabular}

${ }^{a}$ Common name is not available.

\section{$\alpha$-glucosidase inhibition assay}

Rat intestinal $\alpha$-glucosidase inhibition assay of all plant extracts were determined according to the method of Kim et al. [26] with slightly modification. Rat-intestinal acetone powder (0.5 g) (I1630, Sigma-Aldrich, USA) was suspended in $10 \mathrm{~mL}$ of $0.9 \%$ saline. The suspension was sonicated 15 times, $30 \mathrm{~s}$ each time at $4{ }^{\circ} \mathrm{C}$, centrifuged at $10000 \times \mathrm{g}$ for $15 \mathrm{~min}$ at $4{ }^{\circ} \mathrm{C}$. The resulting supernatant was used in this assay. To perform this assay, solution of plant extract sample $(50 \mu \mathrm{L}, 1 \mathrm{mg} / \mathrm{mL}$ in $30 \%$ ethanol) or acarbose $(1 \mathrm{mg} / \mathrm{mL}$, positive control) was pre-incubated with $100 \mu \mathrm{L}$ of rat intestinal $\alpha$-glucosidase at 37 ${ }^{\circ} \mathrm{C}$ for $10 \mathrm{~min}$. Then, $50 \mu \mathrm{L}$ of $5 \mathrm{mM} p$-nitrophenyl- $\alpha$-D-glucopyranoside (Calbiochem, Switzerland) in $0.1 \mathrm{M}$ phosphate buffer ( $\mathrm{pH}$ 6.9) was added, and incubated at $37{ }^{\circ} \mathrm{C}$ for $10 \mathrm{~min}$ before measuring the absorbance at $405 \mathrm{~nm}$ using the microplate reader (IEMS Reader MF Type 1401, Thermo Labsystem, Finland). The $30 \%$ ethanol was used as a negative control. The $\alpha$-glucosidase inhibitory activity was calculated as follows; 
http://wjst.wu.ac.th

$\% \alpha$-glucosidase inhibition $=\frac{\text { A control }- \text { A sample }}{\text { A control }} \times 100$

where A control is the absorbance of control and A sample is the absorbance of sample.

Antioxidant activity assay

Antioxidant activity of 33 plant ethanolic extracts was determined by 2 different methods including DPPH radical scavenging activity assay and ferric reducing antioxidant power assay.

\section{DPPH radical scavenging activity assay}

The free radical scavenging activity of the plant extracts was measured according to the method of Brand-Williams et al. [27]. Each stock solution of extracts and $\alpha$-tocopherol (95240; Fluka, Switzerland), a positive control were prepared and diluted to the concentrations of $1-1,000 \mu \mathrm{g} / \mathrm{mL}$ in methanol. Each diluted extract $(75 \mu \mathrm{L})$ at 5 concentrations was added to $2.925 \mathrm{~mL}$ of a $0.025 \mathrm{~g} / \mathrm{L} \mathrm{2}$, 2-diphenyl-1picrylhydrazyl (DPPH; D9132; Sigma-Aldrich, Germany) solution in methanol. The reaction mixtures were then incubated in the dark for $30 \mathrm{~min}$. The absorbance at $515 \mathrm{~nm}$ was measured at 0 and $30 \mathrm{~min}$ of incubation using the UV-Visible spectrophotometer (UV1601, Shimadzu Scientific Instruments (Oceania) Pty. Ltd., Australia). To prepare a standard curve of DPPH, the absorbance of DPPH at different concentrations $(0.025-0.0008 \mathrm{~g} / \mathrm{L})$ was measured at $515 \mathrm{~nm}$. The remaining DPPH concentration in the reaction mixture was calculated from the DPPH standard curve, and the percentage of the remaining $\mathrm{DPPH}^{\circ}$ was calculated using the following equation;

$\% \mathrm{DPPH}_{\mathrm{REM}}^{\cdot}=\left[\mathrm{DPPH}_{\mathrm{T}} /\left[\mathrm{DPPH}_{\mathrm{T}=0} \times 100\right.\right.$

where $\left[\mathrm{DPPH}^{-}\right]_{T}$ and $\left[\mathrm{DPPH}^{-}\right]_{T=0}$ were the concentration of $\mathrm{DPPH}$ at steady state $(30 \mathrm{~min})$ and zero time, respectively.

The percentage of the remaining DPPH in each reaction mixture of 5 different concentrations of all extracts was then plotted against $\mu \mathrm{g}$ of extract $/ \mathrm{mg}$ of DPPH to obtain the amount of antioxidant or extract necessary to decrease the initial $\mathrm{DPPH}$ by $50 \%\left(\mathrm{EC}_{50}\right)$. The $\mathrm{EC}_{50}$ values of all extracts were calculated by the following linear regression of plots, and the antiradical efficiency $\left(\mathrm{AE}=1 / \mathrm{EC}_{50}\right)$ values were also calculated.

$\left[\% \mathrm{DPPH}_{\mathrm{REM}}\right]=b[\mu \mathrm{g}$ antioxidant/mg $\mathrm{DPPH}]+a$

Ferric reducing antioxidant power (FRAP) assay

Antioxidant activity of the plant extracts by the FRAP method was analyzed according to the procedure as previously described by Lado et al. [28]. To do FRAP assay, $1 \mathrm{mg} / \mathrm{mL}$ extract $(100 \mu \mathrm{L})$ was mixed with $3.0 \mathrm{~mL}$ FRAP reagent $(25 \mathrm{~mL}$ of $300 \mathrm{mM}$ acetate buffer, $2.5 \mathrm{~mL}$ of $10 \mathrm{mM}$ 2,4,6-Tris (2pyridyl)-s-triazine (TPTZ; 93285; Fluka, Switzerland) in $40 \mathrm{mM} \mathrm{HCl}$ and $2.5 \mathrm{~mL}$ of $20 \mathrm{mM} \mathrm{FeCl}_{3} \cdot 6 \mathrm{H}_{2} \mathrm{O}$ ), and incubated at $37{ }^{\circ} \mathrm{C}$ for $5 \mathrm{~min}$. The absorbance was measured at $594 \mathrm{~nm}$ using UV-visible spectrophotometer (UV1601, Shimadzu Scientific Instruments (Oceania) Pty. Ltd., Australia) against blank (FRAP reagent without the sample). The concentration of $\mathrm{Fe}^{2+}$-TPTZ (reducing capacity) was calculated by comparing the absorbance at $594 \mathrm{~nm}$ with the standard curve of the Fe (II) standard solutions (ferrous sulfate heptahydrate) at the concentration of $3-0.0469 \mathrm{mM}$. Alpha-tocopherol was used as a positive control. The reducing power of each extract was expressed as mmol Fe(II)/g extract.

Acetylcholinesterase inhibitory activity assay

The anti-acetylcholinesterase activity of all plant extracts was determined according to the method previously reported by Ellman et al. [29] and Sancheti et al. [30] with slightly modification. Acetylcholinesterase from electric eel (E.C. 3.1.1.7, Sigma, Sigma-Aldrich, USA), acetylcholine iodide 
http://wjst.wu.ac.th

(ATCI, Fluka, Sigma-Aldrich, United Kingdom), 5, 5'-dithio-bis (2-nitrobenzoic acid) (DTNB, Sigma, Sigma-Aldrich, USA) were employed. Galanthamine hydrobromide from Lycoris sp. (Sigma, SigmaAldrich, USA) was used as the standard drug. In this method, $240 \mu \mathrm{L}$ acetylcholinesterase solution $(0.025$ $\mathrm{U} / \mathrm{mL}), 120 \mu \mathrm{L}$ sample $(0.1$ and $1 \mathrm{mg} / \mathrm{mL}$ of the plant extract in $30 \%$ ethanol $), 2,160 \mu \mathrm{L}$ Tris-HCl buffer $(50 \mathrm{mM}$ Tris- $\mathrm{HCl}, \mathrm{pH} 8)$ were mixed and incubated at $4{ }^{\circ} \mathrm{C}$ for $30 \mathrm{~min}$. Then, $240 \mu \mathrm{L} \mathrm{DTNB}(0.3 \mathrm{mM})$ and $240 \mu \mathrm{L}$ ATCI $(1.8 \mathrm{mM})$ were added. The reaction mixture was incubated at $37{ }^{\circ} \mathrm{C}$ for $20 \mathrm{~min}$. Then, the absorbance was measured at $412 \mathrm{~nm}$ using UV-visible spectrophotometer (UV1601, Shimadzu Scientific Instruments (Oceania) Pty. Ltd., Australia). The blank was prepared for correcting the background absorbance, in which the acetylcholinesterase enzyme was replaced by buffer. Control was performed in the same manner by replacing the sample with $30 \%$ methanol. The percentage of inhibition was calculated using the following formula;

$\%$ inhibition $=\frac{\text { A control }- \text { A sample }}{\text { A control }} \times 100$

where A control and A sample are the absorbance values of the control and the sample, respectively.

\section{Determination of total phenolic content}

Total phenolic content of crude ethanolic extract of each plant sample was determined according to the method as described by Singleton et al. [31]. The sample $(0.1 \mathrm{~mL}$ of $1 \mathrm{mg} / \mathrm{mL}$ crude extract in $30 \%$ ethanol) was transferred to a test tube, then $6 \mathrm{~mL}$ ultra-pure water was added. Folin-Ciocalteu's phenol reagent (UN3264, VWR chemical, European Commission) (500 $\mu \mathrm{L})$ was added, shaken thoroughly, and allowed to stand for $1 \mathrm{~min}$. Then, $1.5 \mathrm{~mL}$ of $20 \% \mathrm{Na}_{2} \mathrm{CO}_{3}$ and $1.9 \mathrm{~mL}$ of ultra-pure water were added, mixed well and incubated for $30 \mathrm{~min}$ at $25{ }^{\circ} \mathrm{C}$. After incubation, the absorbance was measured at $760 \mathrm{~nm}$ using UV-visible spectrophotometer (UV1601, Shimadzu Scientific Instruments (Oceania) Pty. Ltd., Australia). Standard curve of gallic acid (48630; Fluka, Spain) at $10-1,000 \mu \mathrm{g} / \mathrm{mL}$ concentration was prepared. The total phenolic contents in each plant extracts were calculated from the linear equation of the gallic acid standard curve. The results were expressed as mg gallic acid equivalents (GAE) / g extract.

\section{Determination of total flavonoid content}

Total flavonoid contents in all samples were analyzed according to the method of Kathirvel and Sujatha [32]. The plant extract $(250 \mu \mathrm{L}$ of $1 \mathrm{mg} / \mathrm{mL}$ extract in $30 \%$ ethanol) was transferred to a test tube and mixed with $1.25 \mathrm{~mL}$ distilled water and $75 \mu \mathrm{L}$ of $5 \% \mathrm{NaNO}_{2}(\mathrm{w} / \mathrm{w})$. After $5 \mathrm{~min}, 150 \mu \mathrm{L}$ of $10 \%$ $\mathrm{AlCl}_{3}(\mathrm{w} / \mathrm{w})$ was added and allowed to stand for $6 \mathrm{~min}$ at room temperature. Then, $500 \mu \mathrm{L}$ of $1 \mathrm{M} \mathrm{NaOH}$ and $275 \mu \mathrm{L}$ of distilled water were added. The mixture was mixed well, and the absorbance was measured at $510 \mathrm{~nm}$ using UV-visible spectrophotometer (UV1601, Shimadzu Scientific Instruments (Oceania) Pty). Catechin (Catechin hydrate, 22110, Aldrich, Germany) at $10-1,000 \mu \mathrm{g} / \mathrm{mL}$ final concentration was used to plot a standard curve. The $30 \%$ ethanol was used as a blank sample. Total flavonoid contents in all samples were expressed as mg catechin eqivalents (CE)/g extract.

\section{Determination of prebiotic properties}

The indigestible polysaccharide content in all plant extracts were analyzed according to the method of Wichienchot et al. [33]. The acidic digestion was performed by mixing $3 \mathrm{~mL}$ of each plant extract (1 $\mathrm{mg} / \mathrm{mL}$ in $30 \%$ ethanol) with $\mathrm{HCl}$ buffer $(\mathrm{pH} 1)$. Then, $1 \mathrm{~mL}$ of this mixture was analyzed for the total sugar content before digestion using dinitrosalicylic acid method, modified from the method of Miller [34]. The rest of this mixture was incubated at $37{ }^{\circ} \mathrm{C}$ for $4 \mathrm{~h}$ before the reaction was terminated by adding $1 \mathrm{~N} \mathrm{NaOH}$. This acid-digested solution was further digested by 2 unit/mL $\alpha$-amylase (A6255; from porcine pancreas; Fluka; Switzerland) in phosphate buffer ( $\mathrm{pH} 7)$ for $6 \mathrm{~h}$. After heating to $80{ }^{\circ} \mathrm{C}$ for 10 min, the total sugar content was analyzed using phenol-sulfuric method [35]. The indigestible polysaccharide content $(\mathrm{mg} / \mathrm{g}$ extract) in the sample was calculated by subtracting the total sugar after digestion (mg/g extract) with the total sugar before digestion $(\mathrm{mg} / \mathrm{g}$ extract). 


\section{Effect of fruit and vegetable extracts on growth of lactic acid bacteria during yogurt fermentation \\ Bacterial strains and starter culture preparation}

Three species of lactic acid bacteria (LAB) were used in this study (Lactobacillus acidophilus TISTR 1034 and Lactobacillus bulgaricus TISTR 451, obtained from the Microbiological Resources Centre for Southeast Asian Region (Bangkok MIRCEN), Thailand and Streptococcus thermophilus BCC 5366, obtained from BIOTEC Culture Collection, National Center for Genetic Engineering and Biotechnology, Pathum Thani, Thailand). They were subcultured twice onto deMan Rogosa Sharpe (MRS) agar (Difco Laboratories, USA) and incubated for $24 \mathrm{~h}$ at $37^{\circ} \mathrm{C}$. Then, a loopful of each LAB strain was inoculated into $5 \mathrm{~mL}$ of MRS broth. After incubation, cells were collected by centrifugation at $3000 \times \mathrm{g}$ for $15 \mathrm{~min}$, washed twice and resuspended in $0.1 \%$ peptone water. Turbidity was adjusted to match the turbidity of $5 \mathrm{McF}$ arland standard to obtain an inoculum concentration of $10^{8} \mathrm{CFU} / \mathrm{mL}$.

\section{Fermentation of yogurt supplemented with fruit and vegetable extracts}

In the current study, 5 plant extracts with high indigestible polysaccharide content were selected to study their effect on the growth of the starter culture according to the modified method of Agil et al. [36]. In brief, seven treatments of yogurt were produced: treatment 1 - 5, yogurt made from milk supplemented with each of 5 plant extracts; treatment 6 (positive control), yogurt made from milk supplemented with $4 \%$ inulin (I2255; from chicory; Sigma-Aldrich; St. Louis, MO, USA) and treatment 7 (negative control), yogurt made from milk only. To produce yogurt, full fat milk with $3.56 \%$ fat and $12.32 \%$ total solid was used. Skim milk powder ( $5 \%$ ) was added into this milk to get $18 \%$ total solid. The mixture was warmed up to $50{ }^{\circ} \mathrm{C}$ and homogenized. Then, all treatment mixtures were pasteurized at $85{ }^{\circ} \mathrm{C}$ for $15 \mathrm{~min}$, and cooled down to $42{ }^{\circ} \mathrm{C}$ before inoculating with $2 \%$ starter culture $(24 \mathrm{~h}$ old mixed culture of $L$. acidophilus TISTR 1034, L. bulgaricus TISTR 451 and S. thermophilus BCC $5366(1: 1: 1, \mathrm{v} / \mathrm{v} / \mathrm{v})$ in whole milk at $42{ }^{\circ} \mathrm{C}$ ). All samples were incubated at $42{ }^{\circ} \mathrm{C}$ for $24 \mathrm{~h}$. At 0,12 and $24 \mathrm{~h}$ fermentation, the yogurt samples of each treatment were taken for measurement of $\mathrm{pH}$ value, total acidity [37] and evaluation of total $\mathrm{LAB}$ counts using spiral plate technique by spiral plater (Autoplate 4000, Spiral Biotech, USA) on MRS agar. The experiments were done in triplicate. All data were analyzed by ANOVA and Duncan's multiple range test at $95 \%$ confidence level using the IBM SPSS 22.0 version statistical package, USA.

\section{Results and discussion}

\section{Antidiabetic activity}

Bamboo grass ( $T$. triandra) leaf extract had strongest $\alpha$-amylase inhibitory activity $(78.28 \%$ inhibition), followed by the extracts of common garlic, salak plum, Indian gooseberry, sweet corn, star apple, Jerusalem artichoke, pineapple, karunda, gac fruit, lopea tree and great morinda $(21.33-37.12 \%$ inhibition), but other plant extracts had relatively low $\alpha$-amylase inhibitory activity. For $\alpha$-glucosidase inhibitory activity, only mulberry $(M . a l b a)$ fruit extract had strongest $\alpha$-glucosidase inhibitory activity (59.63\% inhibition) among all extracts (Table 2).

Bamboo grass leaf extract has been reported to contain some polyphenol compounds such as $p$ hydroxybenzoic acid, minecoside, flavone glycoside cinnamic acids derivative, monoepoxybetacarotene, santonin, protopseudohypericin, 3-O-methylluteolin glucoside malonylated, 3-demethoxy- $9 \alpha$ hydroxyligballinol- $O$-glucoside and flavanone glycoside [38]. Flavonoids including flavonols, flavones, catechins, flavanones and some other flavonoids are natural compounds having potential hypoglycemic properties. Flavonoids (flavonols, flavones, catechins, quercetins, flavanones and others) help to improve altered glucose and oxidative metabolism [1]. Vessal et al. [39] reported that intraperitoncal administration of quercetin in streptozocin-induced diabetic rats could decrease glucose level in their blood stream. Plant extracts with $\alpha$-amylase inhibitory activity may be antidiabetic as $\alpha$-amylase is an enzyme hydrolysed $\alpha-(1,4)$-glucosidic linkage of starch into maltose and glucose. Inhibition of this enzyme may delay absorption of glucose into blood stream and help to alleviate the symptom of type 2- 
http://wjst.wu.ac.th

diabetes. Therefore, it is possible that bamboo grass leaves with high flavonoids could have antidiabetic activity.

For antidiabetic activity of garlic extract, it has been reported that garlic extract administration in rats $(0.1-0.5 \mathrm{~g} / \mathrm{kg}$ body weight) resulted in reducing of serum glucose level, total cholesterol, triglycerides, urea, uric acid, aspartate amino transferase and alanine amino transferase in rats as well as increasing of insulin level in blood serum of streptozotocin-induced diabetic rats [40]. Garlic contains some active compounds including sulfur compounds (allicin and S-allylcysteine) and organic sulfur compounds (thiosulfinates ajoenes and allicin, diallyl thiosulphate) which are good for health. Sallylcysteine is one of the active compounds in garlic that will help to maintain the serum glucose level in blood, insulin level in plasma and growth rate of streptozotocin-induced diabetic rats to normal level [41].

The extract of Pak Chiangda ( $G$. inodorum) had not too strong $\alpha$-amylase and $\alpha$-glucosidase inhibitory activity (13.94 and $3.72 \%$, respectively), but Shimizu et al. [42] reported that crude saponin mixture extracted from $G$. inodorum leaves could inhibit glucose absorption in the isolated intestinal tract and suppressed the increased blood glucose in rats. Pak Chiangda is a vegetable widely used in Northern Thai food. Chiabchalard et al. [43]. reported that significant decrease of peak plasma glucose was observed in healthy human after comsumption of $G$. inodorum tea with meal or 15 min after meal.

Mulberry (M. alba) fruit extract had strongest $\alpha$-glucosidase inhibitory activity. The $\alpha$-glucosidase, an enzyme in lumen of intestine and in brush border membrane, hydrolyses starch and oligosaccharide into monosaccharide before being absorbed. Inhibition of this enzyme delays carbohydrate digestion, thereby controlling blood glucose levels in patients [44]. Strong $\alpha$-glucosidase inhibitory activity in mulberry fruits is probably due to the effect of its active compound such as 1-deoxynojirimycin which is the hypoglycemic constituent found in Morus alba tree [45]. Jiao et al. [46] reported that M. alba fruit polysaccharide had antihyperglycemic effect and could relieve diabetic symptoms in Type 2 diabetes mellitus rat model. Moreover, the polysaccharide isolated from leaves of $M$. alba has been reported to enhance pancreatic $\beta$-cell regeneration and insulin secretion in streptozotocin-induced diabetic rats [47].

\section{Antioxidant and anti-acetylcholinesterase activities, phenolics and flavonoids}

Of all, the extracts of mangosteen (G. mangostana) fruit peels and Indian gooseberry ( $P$. emblica) fruits had strongest antioxidant activity by DPPH radical scavenging activity $(2.20-2.27$ antiradical efficiency) and FRAP (2.99 - $3.51 \mathrm{mmol} \mathrm{Fe(II)/g} \mathrm{extract)} \mathrm{methods.} \mathrm{These} 2$ plant extracts contained high amount of total phenolics (416.07 mg GAE/g extract of Indian gooseberry fruits and $397.36 \mathrm{mg}$ GAE/g extract of mangosteen fruit peels). In addition, the extracts which possessed relatively strong antioxidant activity were the extracts of lotus seed $(N$. nucifera), Kamchat ton ( $Z$. limonella) and lopea tree $(A$. trifoliatus) (0.50 - 0.74 antiradical efficiency by DPPH method and $0.80-1.19 \mathrm{mmol} \mathrm{Fe}(\mathrm{II}) / \mathrm{g}$ extract by FRAP method). There were some correlations between the antioxidant activity, total phenolic and flavonoid contents of these extracts (Tables 2 and $\mathbf{3}$ ).

Strong antioxidant activities, and high phenolics and flavonoids in Indian gooseberry fruits, mangosteen fruit peels, lotus seeds, kamchat ton seeds and whole plants of lopea tree may be due to the action of their active compounds. Indian gooseberry extract has been reported to contain gallic acid, ellagic acid, mucic acid 1,4-lactone 3-O-gallate, isocorilagin, chebulanin, chebulagic acid and mallotusinin [48], while $m$-hydroxybenzoic acid and 3,4-dihydroxymandelic were found in the peels and rinds of mangosteen fruits, respectively [49]. Kredy et al. [50] identified the flavonoid compounds in fresh lotus seed epicarp, and found 6 glycosylate flavonols and 1 aglycone flavonol, while Yen et al. [51] reported that lotus seed extract contained some of the active components such as phenolic acid, gallic acid, caffeic acid, chlorogenic acid and $p$-hydroxybenzoic acid. In addition, some compounds isolated from kamchat ton were limonellone, lupeol, alkaloid rutaecarpine and coumarins (xanthoxyletin, osthol and scopoletin) [52].

In addition, main compounds in lopea tree leaf extract were identified as chlorogenic acid and rutin [15]. Phuong et al. [53] reported that diterpenoids (continentalic acid and kaurenoic acid) were found in roots and stems of lopea tree (A. trifoliatus). Lopea tree, an interesting medicinal plants is a shrub that usually thrives in roadsides, valleys or on mountain slopes. The stem barks and leaves of $A$. trifoliatus have been used as an antiflatulent agent and a tonic to improve general weakness, respectively. In 
http://wjst.wu.ac.th

northern of Thailand, young leaves and the shoots of this plant are usually consumed as vegetable [54]. For antioxidant activity of kamchat ton (Z. limonella), it was probably due to its active compounds. Tangjitjaroenkun et al. [55] reported the antioxidant activity of $Z$. limonella stem extract and found that it contained quinolone alkaloid, limonellone and other compounds previously isolated including ubiquitous lupeol, alkaloid rutaecarpine and coumarins (xanthoxyletin, osthol and scopoletin) [52].

Table 2 Antioxidant, antidiabetic and anti-acetylcholinesterase activities of fruit, vegetable and some Thai local food plant extracts.

\begin{tabular}{|c|c|c|c|c|c|c|c|c|}
\hline \multirow{3}{*}{ Scientific name } & \multirow{3}{*}{ Common name } & \multicolumn{3}{|c|}{ Antioxidant activity ${ }^{a}$} & \multicolumn{2}{|c|}{ Antidiabetic activity } & \multicolumn{2}{|c|}{$\begin{array}{c}\text { Anti-acetylcholinesterase } \\
\text { activity }(\%) \pm \text { SD }\end{array}$} \\
\hline & & \multicolumn{2}{|c|}{ DPPH assay } & \multirow{2}{*}{$\begin{array}{c}\text { FRAP assay } \\
(\text { mmol Fe(II)/ } \\
\text { g extract } \pm \text { SD }\end{array}$} & \multirow{2}{*}{$\begin{array}{c}\alpha \text {-amylase } \\
\text { inhibition }(\%) \\
\pm \mathrm{SD}\end{array}$} & \multirow{2}{*}{$\begin{array}{c}\alpha \text {-glucosidase } \\
\text { inhibition }(\%) \\
\quad \pm \text { SD }\end{array}$} & \multirow[b]{2}{*}{$1 \mathrm{mg} / \mathrm{mL}$} & \multirow[b]{2}{*}{$0.1 \mathrm{mg} / \mathrm{mL}$} \\
\hline & & $\begin{array}{c}\mathrm{EC}_{50}(\mu \mathrm{g} \text { extract } / \\
\mathrm{mg} \mathrm{DPPH}) \pm \mathrm{SD}\end{array}$ & $\mathrm{AE}\left(10^{-3}\right) \pm \mathrm{SD}$ & & & & & \\
\hline A. trifoliatus & Lopea tree & $1,982 \pm 3.31$ & $0.50 \pm 0.01$ & $0.93 \pm 0.03$ & $23.25 \pm 1.30$ & $8.07 \pm 1.60$ & $6.78 \pm 0.75$ & $2.89 \pm 0.38$ \\
\hline A. sativum & Common garlic & $74,386.33 \pm 3.48$ & $0.01 \pm 0.00$ & $0.003 \pm 0.00$ & $37.12 \pm 0.90$ & $9.38 \pm 1.10$ & $12.86 \pm 1.15$ & $4.55 \pm 1.81$ \\
\hline A. oschaninii & Shallot & $55,355.19 \pm 0.85$ & $0.02 \pm 0.00$ & $0.02 \pm 0.01$ & $15.43 \pm 1.20$ & $12.83 \pm 5.90$ & $8.61 \pm 1.83$ & $2.93 \pm 0.89$ \\
\hline A. vera & Star cactus & $23,733.02 \pm 3.85$ & $0.04 \pm 0.00$ & $0.07 \pm 0.00$ & $18.24 \pm 1.90$ & $7.85 \pm 2.40$ & $31.55 \pm 1.44$ & $14.04 \pm 2.84$ \\
\hline A. comosus & Pineapple & $62,907.35 \pm 1.86$ & $0.02 \pm 0.00$ & $0.01 \pm 0.01$ & $26.61 \pm 1.10$ & $12.16 \pm 2.50$ & $9.30 \pm 1.54$ & $2.54 \pm 0.19$ \\
\hline A. squamosa & Sugar apple & $3,385.10 \pm 2.72$ & $0.29 \pm 0.01$ & $0.28 \pm 0.01$ & $2.30 \pm 1.80$ & $12.43 \pm 2.20$ & $9.67 \pm 1.12$ & $3.03 \pm 0.24$ \\
\hline C. carandas & Karunda & $3,075.84 \pm 1.54$ & $0.33 \pm 0.01$ & $0.38 \pm 0.00$ & $24.51 \pm 1.50$ & $12.26 \pm 4.00$ & $8.58 \pm 1.50$ & $1.79 \pm 0.61$ \\
\hline C. asiatica & Asiatic pennywort & $4,393.94 \pm 2.43$ & $0.23 \pm 0.00$ & $0.38 \pm 0.02$ & $14.30 \pm 2.10$ & $2.12 \pm 2.00$ & $3.24 \pm 0.78$ & $1.67 \pm 0.13$ \\
\hline C. cainito & Star apple & $3,258.62 \pm 5.44$ & $0.31 \pm 0.00$ & $0.40 \pm 0.00$ & $30.10 \pm 1.40$ & $13.19 \pm 1.90$ & $9.24 \pm 1.75$ & $2.12 \pm 0.88$ \\
\hline D. volubilis & $-{ }^{b}$ & $11,604.20 \pm 0.91$ & $0.09 \pm 0.00$ & $0.14 \pm 0.02$ & $5.68 \pm 1.60$ & $7.98 \pm 2.40$ & $5.29 \pm 1.94$ & $2.63 \pm 1.35$ \\
\hline E. latifolia & Bastard Oleaster & $27,465.56 \pm 1.11$ & $0.04 \pm 0.00$ & $0.07 \pm 0.01$ & $7.52 \pm 1.50$ & $12.59 \pm 3.40$ & $8.51 \pm 0.87$ & $7.30 \pm 1.42$ \\
\hline G. mangostana & Mangosteen & $440.73 \pm 1.31$ & $2.27 \pm 0.01$ & $2.99 \pm 0.08$ & $19.01 \pm 1.20$ & $5.43 \pm 5.70$ & $13.79 \pm 1.71$ & $2.93 \pm 0.49$ \\
\hline G. biloba & Maidenhair tree & $6,229.66 \pm 1.35$ & $0.16 \pm 0.00$ & $0.37 \pm 0.02$ & $16.43 \pm 1.20$ & $14.47 \pm 3.30$ & $8.08 \pm 1.07$ & $2.48 \pm 0.89$ \\
\hline G. inodorum & Gymnema & $8,366.34 \pm 4.55$ & $0.12 \pm 0.00$ & $0.23 \pm 0.01$ & $13.94 \pm 1.30$ & $3.72 \pm 2.40$ & $9.02 \pm 1.57$ & $4.96 \pm 1.42$ \\
\hline H. tuberosus & Jerusalem articheoke & $112,047.80 \pm 4.55$ & $0.04 \pm 0.05$ & $0.01 \pm 0.01$ & $28.84 \pm 1.50$ & $6.45 \pm 2.40$ & $5.51 \pm 1.09$ & $2.63 \pm 0.81$ \\
\hline I. batatas & Purple sweet potato & $34,250.15 \pm 2.90$ & $0.03 \pm 0.00$ & $0.10 \pm 0.01$ & $2.82 \pm 1.20$ & $12.01 \pm 3.20$ & $9.16 \pm 1.76$ & $3.48 \pm 1.40$ \\
\hline I. batatas & Orange sweet potato & $103,368.80 \pm 3.31$ & $0.01 \pm 0.00$ & $0.02 \pm 0.01$ & $5.32 \pm 1.00$ & $14.41 \pm 1.80$ & $9.75 \pm 1.82$ & $3.51 \pm 1.32$ \\
\hline M. domestica & Red apple & $26,825.12 \pm 1.68$ & $0.04 \pm 0.00$ & $0.03 \pm 0.01$ & $19.04 \pm 0.90$ & $13.50 \pm 3.30$ & $5.87 \pm 0.49$ & $1.45 \pm 0.41$ \\
\hline M. citrifolia & Great morida & $23,035.48 \pm 4.87$ & $0.04 \pm 0.00$ & $0.06 \pm 0.01$ & $21.33 \pm 1.40$ & $11.35 \pm 2.40$ & $10.45 \pm 0.11$ & $4.42 \pm 0.79$ \\
\hline M. alba & Mulberry & $8,020.26 \pm 5.65$ & $0.12 \pm 0.01$ & $0.21 \pm 0.02$ & $18.44 \pm 0.90$ & $59.63 \pm 0.80$ & $4.24 \pm 0.65$ & $2.06 \pm 0.19$ \\
\hline M. cochinchinensis & Gac fruit & $76,993.93 \pm 1.95$ & $0.01 \pm 0.00$ & $0.02 \pm 0.00$ & $23.31 \pm 1.20$ & $9.78 \pm 5.20$ & $9.17 \pm 0.88$ & $3.05 \pm 0.34$ \\
\hline $\begin{array}{l}\text { M. sapientum (AA } \\
\text { group) }\end{array}$ & Lep Mu Nang banana & $58,732.48 \pm 5.18$ & $0.02 \pm 0.00$ & $0.01 \pm 0.00$ & $1.76 \pm 1.20$ & $10.61 \pm 4.10$ & $9.17 \pm 1.50$ & $2.09 \pm 0.35$ \\
\hline $\begin{array}{l}\text { M. sapientum (AA } \\
\text { Khai) }\end{array}$ & Pisang Mas banana & $7,690.25 \pm 2.59$ & $0.13 \pm 0.00$ & $0.38 \pm 0.01$ & $3.74 \pm 1.30$ & $5.55 \pm 0.30$ & $4.26 \pm 1.14$ & $1.51 \pm 0.51$ \\
\hline $\begin{array}{l}\text { M. sapientum } \\
\text { (Musa ABB cv. } \\
\text { Kluai 'Namwa') }\end{array}$ & Cultivated banana & $6,978.51 \pm 4.34$ & $0.14 \pm 0.00$ & $0.19 \pm 0.02$ & $2.67 \pm 2.00$ & $11.50 \pm 2.40$ & $5.36 \pm 0.71$ & $1.63 \pm 0.63$ \\
\hline N. nucifera & Lotus seed & $1,340.86 \pm 4.56$ & $0.74 \pm 0.00$ & $0.80 \pm 0.23$ & $10.22 \pm 1.70$ & $4.01 \pm 1.10$ & $11.81 \pm 0.95$ & $5.60 \pm 1.08$ \\
\hline O. sativa & Black rice & $4,294.95 \pm 4.38$ & $0.23 \pm 0.00$ & $0.44 \pm 0.02$ & $7.84 \pm 1.60$ & $4.57 \pm 3.20$ & $13.27 \pm 1.64$ & $5.51 \pm 0.87$ \\
\hline P. laurifolia & Passion fruit & $8,644.88 \pm 5.81$ & $0.12 \pm 0.00$ & $0.15 \pm 0.01$ & $18.24 \pm 1.40$ & $15.09 \pm 3.30$ & $10.99 \pm 0.45$ & $4.15 \pm 0.87$ \\
\hline P. emblica & Indian gooseberry & $453.50 \pm 2.15$ & $2.20 \pm 0.01$ & $3.51 \pm 0.03$ & $31.31 \pm 1.00$ & $11.04 \pm 2.50$ & $17.36 \pm 2.34$ & $5.57 \pm 1.10$ \\
\hline S. zalacca & Salak plum & $53,427.08 \pm 4.27$ & $0.02 \pm 0.00$ & $0.01 \pm 0.01$ & $32.53 \pm 1.50$ & $12.07 \pm 2.20$ & $6.66 \pm 0.83$ & $2.27 \pm 0.53$ \\
\hline T. triandra & Bamboo grass & $6,346.05 \pm 1.17$ & $0.16 \pm 0.00$ & $0.27 \pm 0.02$ & $78.28 \pm 0.30$ & $10.30 \pm 1.80$ & $4.60 \pm 0.85$ & $2.18 \pm 0.61$ \\
\hline Z. limonella & Kamchat ton & $1,511.89 \pm 2.31$ & $0.66 \pm 0.00$ & $1.19 \pm 0.02$ & $1.39 \pm 1.20$ & $5.69 \pm 4.20$ & $8.96 \pm 1.33$ & $6.33 \pm 0.56$ \\
\hline Z. mays & Sweet corn & $144,948.80 \pm 6.31$ & $0.01 \pm 0.00$ & $0.01 \pm 0.01$ & $30.73 \pm 0.90$ & $10.90 \pm 1.00$ & $5.34 \pm 1.05$ & $2.00 \pm 0.57$ \\
\hline Z. zerumbet & Shampoo ginger & $11,579.44 \pm 5.41$ & $0.09 \pm 0.00$ & $0.07 \pm 0.02$ & $9.41 \pm 1.80$ & $7.27 \pm 4.70$ & $10.50 \pm 1.16$ & $7.42 \pm 0.56$ \\
\hline Galanthamine & Galanthamine & $-\mathrm{c}$ & - & - & - & - & $82.40 \pm 0.83$ & $77.34 \pm 1.73$ \\
\hline$\alpha$-Tocopherol & Vitamin E & $505.35 \pm 4.25$ & $1.98 \pm 0.02$ & $0.59 \pm 0.04$ & - & - & - & - \\
\hline Acarbose & Positive control & - & - & - & $96.02 \pm 0.4$ & $96.56 \pm 1.10$ & - & - \\
\hline
\end{tabular}

${ }^{\text {a }}$ Data are mean of 3 replications.

${ }^{\mathrm{b}}$ Common name is not available. 
http://wjst.wu.ac.th

The extract of star apple (C. cainito) had moderate antioxidant activity ( 0.31 antiradical efficiency and $0.40 \mathrm{mmol} \mathrm{Fe}(\mathrm{II}) / \mathrm{g}$ extract by DPPH and FRAP method, respectively), but not the extract of malodge (E. latifolia fruit) (0.04 antiradical efficiency and $0.07 \mathrm{mmol} \mathrm{Fe}(\mathrm{II}) / \mathrm{g}$ extract by DPPH and FRAP method, respectively). Star apple is a local plant in central America and can be found in northern Thailand. Its fruits look like a pear fruit. The color of fruit pulp is purple red or pale green, sweet taste and fragrance odor. Morton et al. [56] reported that the fruits of star apple contained 67.2 calories which came from $0.72-2.33 \mathrm{~g}$ protein, $14.7 \mathrm{~g}$ carbohydrate and $0.55-3.33 \mathrm{~g}$ dietary fiber, and also contained carotene, thiamine, riboflavin, niacin and vitamin C. Kubola et al. [11] reported the antioxidant activity of this fruit extract, and found that its ripe fruits contained phenolic acids (hydrobenzoic acid, gallic acid and protocatechuic acid), hydrocinnamic acid (chlorogenic acid and ferulic acid) and flavonoids (rutin, myricetin, luteotin, quercetin, apigenin and kaempferol). Differently, malodge (E. latifolia) is a fruit with sour taste. The ripe fruits are orange or red in color. It has been used for treatment of laxative. This plant has rarely been studied. Seal [57] revealed that fruits of E. latifolia contained crude protein $(148.2 \mathrm{~g} / \mathrm{kg})$, carbohydrate $(743 \mathrm{~g} / \mathrm{kg})$, crude fiber $(7 \mathrm{~g} / \mathrm{kg})$ and nutritive value $(3,702.73 \mathrm{kcal} / \mathrm{kg})$.

However, only star cactus (Aloe vera) gel extract had higher anti-acetylcholinesterase activity (31.55\% inhibition), compared to other plant extracts. Bawankar et al. [58] identified active compounds in star cactus and found that it contained $22.22 \%$ hexadecanoic acid, $16.2 \%$ 9-octadecenoic acid, $5.59 \%$ tricosane, $5.2 \%$ 1-octadecanol and other compounds in small amount. In the current study, lotus ( $N$. nucifera) seed extract had anti-acetylcholinesterase activity of $11.81 \%$ inhibition, even though the extract of lotus seed embryos has been found to relieve memory loss in rat by inhibiting acetylcholinesterase in hippocampus [59]. This was probably due to the action of active compounds in lotus seed. Lotus is a water plant with strong pharmacological activity. The stamens of $N$. nucifera have been demonstrated an improvement in memory in rat [60].

\section{Indigestible polysaccharide contents}

The extracts with relatively high indigestible polysaccharides $(120.34-188.62 \mathrm{mg} / \mathrm{mL})$ were mangosteen, shallot, bastard oleaster, pineapple, lotus seed, purple sweet potato, black rice, Jerusalem artichoke, pisang mas banana, salak plum, orange sweet potato, cultivated banana and lep mu nang banana extracts (Table 3). Based on their indigestible polysaccharide content, antioxidant activity and flavor, the extracts of lotus seed, black rice, pisang mas banana, cultivated banana and pineapple were selected to study their effect on growth and fermentation of L. acidophilus, L. bulgaricus and $S$. thermophilus during yogurt fermentation.

\section{Effect of plant extracts on growth and fermentation of probiotic bacteria in yogurt}

At the beginning of fermentation, all treatments had slightly different viable counts $(6.46-6.54 \log$ $\mathrm{CFU} / \mathrm{g}$ ) of lactic acid bacteria (LAB). After $12 \mathrm{~h}$ fermentation, total LAB counts in all treatments increased by $1.29-1.77 \log$ unit. The samples added with the extract of lotus seed, pisang mas banana, cultivated banana or pineapple had significantly higher total LAB counts than the control treatment $(\mathrm{P}<$ 0.05). After $24 \mathrm{~h}$ fermentation, yogurt fortified with lotus seed extract had highest number of total LAB (2.24 $\log \mathrm{CFU} / \mathrm{g}$ increase), followed by those of black rice, pisang mas banana and pineapple extracts. Addition of black rice, pisang mas banana and pineapple extracts caused good growth of LAB (2.12 $2.19 \log \mathrm{CFU} / \mathrm{g}$ increase) which may relate to their high indigestible polysaccharides (Tables 3 and 4). The $\mathrm{pH}$ values of all yogurt samples decreased to $3.84-4.84$ after $24 \mathrm{~h}$ fermentation, while the total acidity increased to $0.41-1.29 \%$. The $\mathrm{pH}$ values of the yogurt samples fortified with each of plant extracts had significantly lower $\mathrm{pH}$ values $(\mathrm{pH} 3.84-4.54)$ at the end of fermentation, compared to the sample fortified with inulin $(\mathrm{pH} \mathrm{4.51)}$ and the control treatment $(\mathrm{pH} \mathrm{4.84)}(\mathrm{P}<0.05)$. Fortification with the extracts of pisang mas banana, cultivated banana and pineapple may result in more sour taste of yogurt, compared to others (Table 5). 
http://wjst.wu.ac.th

Table 3 Phenolic, flavonoid and indigestible polysaccharide contents in fruits, vegetables and some Thai local food plant extracts.

\begin{tabular}{|c|c|c|c|c|}
\hline Scientific name & Common name & $\begin{array}{c}\text { Total Phenolics }{ }^{\mathrm{a}}(\mathrm{mg} \\
\text { GAE / g extract) } \pm \text { SD }\end{array}$ & $\begin{array}{l}\text { Total flavonoids }^{\mathrm{a}} \\
\text { (mg CE / g } \\
\text { extract) } \pm \text { SD }\end{array}$ & $\begin{array}{c}\text { Indigestible } \\
\text { polysaccharide }^{\mathrm{a}} \\
(\mathrm{mg} / \mathrm{g} \text { extract }) \pm \mathrm{SD}\end{array}$ \\
\hline A. trifoliatus & Lopea tree & $149.86 \pm 0.64$ & $113.25 \pm 2.40$ & $3.27 \pm 1.50$ \\
\hline A. sativum & Common garlic & $61.86 \pm 2.73$ & $1.51 \pm 1.47$ & $95.05 \pm 4.40$ \\
\hline A. oschaninii & Shallot & $66.62 \pm 1.30$ & $1.60 \pm 1.47$ & $168.69 \pm 3.10$ \\
\hline A. vera & Star cactus & $72.49 \pm 2.66$ & $5.01 \pm 1.39$ & $70.75 \pm 4.70$ \\
\hline A. comosus & Pineapple & $63.40 \pm 1.86$ & $1.68 \pm 1.34$ & $155.23 \pm 1.00$ \\
\hline A. squamosal & Sugar apple & $98.74 \pm 0.73$ & $30.58 \pm 0.66$ & $87.32 \pm 5.70$ \\
\hline C. carandas & Karunda & $98.46 \pm 0.49$ & $43.75 \pm 1.43$ & $57.39 \pm 1.80$ \\
\hline C. asiatica & Asiatic pennywort & $82.11 \pm 3.22$ & $18.01 \pm 1.62$ & $35.81 \pm 2.20$ \\
\hline C. cainito & Star apple & $92.73 \pm 3.78$ & $9.21 \pm 0.97$ & $25.91 \pm 4.70$ \\
\hline D. volubilis & $-\mathrm{b}$ & $87.70 \pm 1.34$ & $13.65 \pm 0.93$ & $7.80 \pm 3.80$ \\
\hline E. latifolia & Bastard Oleaster & $70.24 \pm 2.68$ & $2.62 \pm 1.33$ & $155.51 \pm 4.80$ \\
\hline G. mangostana & Mangosteen & $397.36 \pm 2.77$ & $351.60 \pm 3.71$ & $188.62 \pm 3.60$ \\
\hline G. biloba & Maidenhair tree & $123.60 \pm 2.34$ & $24.57 \pm 3.23$ & $71.81 \pm 2.70$ \\
\hline G. inodorum & Gymnema & $105.16 \pm 2.92$ & $23.98 \pm 2.33$ & $13.47 \pm 4.20$ \\
\hline H. tuberosus & Jerusalem articheoke & $62.00 \pm 1.92$ & $3.90 \pm 1.32$ & $130.13 \pm 1.00$ \\
\hline I batatas & Purple sweet potato & $69.69 \pm 1.17$ & $8.43 \pm 1.12$ & $137.13 \pm 3.00$ \\
\hline I. batatas & Orange Sweet potato & $63.82 \pm 2.10$ & $5.95 \pm 1.69$ & $125.91 \pm 1.40$ \\
\hline M. domestica & Red apple & $66.20 \pm 2.30$ & $5.36 \pm 1.16$ & $109.04 \pm 1.30$ \\
\hline M. citrifolia & Great morinda & $72.48 \pm 3.27$ & $8.09 \pm 1.13$ & $17.77 \pm 1.60$ \\
\hline M. alba & Mulberry & $87.84 \pm 2.26$ & $16.56 \pm 0.57$ & $100.09 \pm 2.20$ \\
\hline M. cochinchinensis & Gac fruit & $66.48 \pm 2.33$ & $3.82 \pm 1.58$ & $6.81 \pm 3.00$ \\
\hline M. sapientum (AAgroup) & Lep Mu Nang banana & $61.16 \pm 1.92$ & $1.51 \pm 1.21$ & $120.34 \pm 2.80$ \\
\hline M. sapientum (AA Khai) & Pisang Mas banana & $98.46 \pm 0.49$ & $33.23 \pm 0.27$ & $129.22 \pm 3.10$ \\
\hline $\begin{array}{l}\text { M. sapientum (Musa } \\
\text { ABB cv. Kluai Namwa) }\end{array}$ & Cultivated banana & $73.73 \pm 2.97$ & $8.77 \pm 1.13$ & $124.85 \pm 1.90$ \\
\hline N. nucifera & Lotus seed & $122.75 \pm 3.84$ & $89.37 \pm 2.46$ & $147.49 \pm 4.90$ \\
\hline O. sativa & Black rice & $113.12 \pm 2.25$ & $38.34 \pm 2.64$ & $136.91 \pm 4.30$ \\
\hline P. laurifolia & Passion fruit & $85.33 \pm 1.14$ & $16.98 \pm 1.55$ & $55.31 \pm 4.90$ \\
\hline P. emblica & Indian gooseberry & $416.07 \pm 6.11$ & $48.88 \pm 3.06$ & $31.90 \pm 1.90$ \\
\hline S. zalacca & Salak plum & $62.57 \pm 1.63$ & $2.54 \pm 0.84$ & $127.76 \pm 4.60$ \\
\hline T. triandra & Bamboo grass & $101.25 \pm 1.81$ & $22.63 \pm 1.53$ & $18.18 \pm 1.60$ \\
\hline Z. limonella & Kamchat ton & $190.52 \pm 3.94$ & $135.36 \pm 1.63$ & $2.28 \pm 0.60$ \\
\hline Z. mays var. saccharata & Sweet corn & $62.99 \pm 0.66$ & $1.17 \pm 1.23$ & $74.54 \pm 3.30$ \\
\hline Z. zerumbet & Shampoo ginger & $82.25 \pm 3.27$ & $4.41 \pm 1.82$ & $69.41 \pm 2.20$ \\
\hline Inulin & - & - & - & $396.57 \pm 1.30$ \\
\hline
\end{tabular}

${ }^{a}$ Data are mean of 3 replications.

${ }^{\mathrm{b}}$ Common name is not available. 
http://wjst.wu.ac.th

Table 4 Change of total lactic acid bacteria in yogurt fortified with different plant extract during fermentation at $42{ }^{\circ} \mathrm{C}$.

\begin{tabular}{|c|c|c|c|}
\hline \multirow{2}{*}{ Treatment $^{x}$} & \multicolumn{3}{|c|}{ Total lactic acid bacteria $(\log \mathrm{CFU} / \mathrm{g})^{\mathrm{y}} \pm \mathrm{SD}$} \\
\hline & $\mathbf{0 ~ h}$ & $12 \mathrm{~h}$ & $24 \mathrm{~h}$ \\
\hline Lotus seed & $6.54 \pm 0.02^{\mathrm{a}}$ & $8.00 \pm 0.01^{\mathrm{b}}$ & $8.78 \pm 0.03^{\mathrm{a}}$ \\
\hline Black rice & $6.51 \pm 0.08^{\mathrm{a}}$ & $7.92 \pm 0.05^{\mathrm{bc}}$ & $8.70 \pm 0.07^{\mathrm{ab}}$ \\
\hline Pisang mas banana & $6.52 \pm 0.04^{\mathrm{a}}$ & $8.28 \pm 0.12^{\mathrm{a}}$ & $8.66 \pm 0.10^{\mathrm{ab}}$ \\
\hline Cutivated banana & $6.49 \pm 0.02^{\mathrm{a}}$ & $8.20 \pm 0.11^{\mathrm{a}}$ & $8.51 \pm 0.02^{\mathrm{cd}}$ \\
\hline Pineapple & $6.46 \pm 0.02^{\mathrm{a}}$ & $8.23 \pm 0.09^{\mathrm{a}}$ & $8.58 \pm 0.03^{\text {bc }}$ \\
\hline Inulin & $6.53 \pm 0.03^{\mathrm{a}}$ & $7.82 \pm 0.02^{\mathrm{c}}$ & $8.52 \pm 0.15^{\mathrm{cd}}$ \\
\hline Control $^{\mathrm{z}}$ & $6.52 \pm 0.06^{\mathrm{a}}$ & $7.82 \pm 0.04^{\mathrm{c}}$ & $8.41 \pm 0.03^{\mathrm{d}}$ \\
\hline
\end{tabular}

${ }^{\mathrm{a}, \mathrm{b}, \mathrm{c}, \mathrm{d}}$ Different letter in different row of the same column indicates significant different $(\mathrm{P}<0.05)$.; ${ }^{\mathrm{x}}$ yogurt sample fortified with each of plant extracts; ${ }^{\mathrm{y}}$ Data are mean of 3 replications.; ${ }^{\mathrm{z}}$ yogurt sample without fortification of plant extract.

Table 5 Change of $\mathrm{pH}$ value and total acidity in yogurt fortified with different plant extract during fermentation at $42{ }^{\circ} \mathrm{C}$

\begin{tabular}{|c|c|c|c|c|c|c|}
\hline \multirow{3}{*}{ Treatment $^{\mathrm{x}}$} & \multicolumn{6}{|c|}{ pH value and total acidity $(\%)^{y} \pm S D$} \\
\hline & \multicolumn{2}{|c|}{$\mathbf{0 ~ h}$} & \multicolumn{2}{|c|}{$12 \mathrm{~h}$} & \multicolumn{2}{|c|}{$24 \mathrm{~h}$} \\
\hline & pH & total acidity & pH & total acidity & pH & total acidity \\
\hline Lotus seed & $6.26 \pm 0.02^{b}$ & $0.18 \pm 0.02^{b}$ & $5.24 \pm 0.04^{b}$ & $0.34 \pm 0.05^{\mathrm{d}}$ & $4.42 \pm 0.01^{\mathrm{c}}$ & $0.55 \pm 0.01^{\mathrm{c}}$ \\
\hline Black rice & $6.28 \pm 0.01^{\mathrm{b}}$ & $0.20 \pm 0.01^{\mathrm{b}}$ & $5.27 \pm 0.03^{\mathrm{b}}$ & $0.31 \pm 0.02^{\mathrm{d}}$ & $4.54 \pm 0.02^{\mathrm{b}}$ & $0.51 \pm 0.00^{\mathrm{d}}$ \\
\hline $\begin{array}{l}\text { Pisang mas } \\
\text { Banana }\end{array}$ & $6.19 \pm 0.02^{\mathrm{c}}$ & $0.20 \pm 0.01^{\mathrm{b}}$ & $4.79 \pm 0.06^{\mathrm{d}}$ & $0.47 \pm 0.01^{\mathrm{b}}$ & $3.84 \pm 0.03^{\mathrm{f}}$ & $0.49 \pm 0.01^{\mathrm{e}}$ \\
\hline $\begin{array}{l}\text { Cultivated } \\
\text { Banana }\end{array}$ & $6.25 \pm 0.03^{b}$ & $0.18 \pm 0.00^{b}$ & $5.02 \pm 0.02^{\mathrm{c}}$ & $0.39 \pm 0.01^{\mathrm{c}}$ & $4.04 \pm 0.04^{\mathrm{d}}$ & $0.57 \pm 0.01^{b}$ \\
\hline Pineapple & $5.86 \pm 0.03^{\mathrm{d}}$ & $0.31 \pm 0.03^{\mathrm{a}}$ & $4.98 \pm 0.01^{\mathrm{c}}$ & $0.70 \pm 0.02^{\mathrm{a}}$ & $3.91 \pm 0.04^{\mathrm{e}}$ & $1.29 \pm 0.01^{\mathrm{a}}$ \\
\hline Inulin & $6.45 \pm 0.02^{\mathrm{a}}$ & $0.17 \pm 0.01^{\mathrm{b}}$ & $5.64 \pm 0.01^{\mathrm{a}}$ & $0.29 \pm 0.04^{\mathrm{d}}$ & $4.51 \pm 0.02^{b}$ & $0.55 \pm 0.00^{\mathrm{c}}$ \\
\hline Control $^{\mathrm{z}}$ & $6.44 \pm 0.03^{\mathrm{a}}$ & $0.17 \pm 0.02^{\mathrm{b}}$ & $5.67 \pm 0.03^{\mathrm{a}}$ & $0.33 \pm 0.00^{\mathrm{d}}$ & $4.84 \pm 0.01^{\mathrm{a}}$ & $0.41 \pm 0.00^{\mathrm{f}}$ \\
\hline
\end{tabular}

${ }^{\mathrm{a}, \mathrm{b}, \mathrm{c}, \mathrm{d}, \mathrm{e}}$ Different letter in different row of the same column indicates significant different $(\mathrm{P}<0.05)$; ${ }^{\mathrm{x}}$ yogurt sample fortified with each of plant extracts; ${ }^{\mathrm{y}}$ Data are mean of 3 replications.; ${ }^{\mathrm{z}}$ yogurt sample without fortification of plant extract.

Growth stimulation effect of lotus seed extract may relate to its prebiotic property. Prebiotics are short chain indigestible carbohydrates or non-digestible oligosaccharide (oligosaccharide, polysaccharide, resistance starch and sugar polyols). Resistant starch is a part of starch which will not be hydrolysed to Dglucose within $120 \mathrm{~min}$ after food is ingested, but it will be fermented in large intestine [61]. Zhang et al. [62] reported that resistant starch type 3 from lotus seed could enhance the growth of bifidobacteria.

The extracts of black rice, pisang mas banana, pineapple and cultivated banana enhanced the growth of starter bacteria in yogurt. This may result from their high indigestible polysaccharides. Black rice has been reported to contain high amount of insoluble dietary fiber $[63,64]$, while pisang mas banana and cultivated banana contain high amount of resistant starch [65]. In addition, van Loo et al. [66] reported that banana contained prebiotics, inulin and oligofructose $(0.3-0.7 \mathrm{~g} / 100 \mathrm{~g})$. These substances tolerate hydrolyzing in upper part of small intestine and pass through large intestine to be the substrate for the beneficial bacteria (bifidobacteria and lactobacilli). These bacteria use this substrate for growth and 
http://wjst.wu.ac.th

fermentation. This will be beneficial for health of human and animals such as anti-infection in digestive system, improvement of motility of food in the intestine, production of short chain fatty acids for intestinal cancer prevention, appetite control by peptide secretion in the digestive tract, enhancing mineral absorption (calcium, iron and magnesium), decreasing of lipid and cholesterol in some occasion as well as enhancing immune system [64].

\section{Conclusions}

Of all 33 plant extracts, the most potent inhibitors against $\alpha$-amylase, $\alpha$-glucosidase and acetylcholinesterase were bamboo grass leaves, mulberry fruits and star cactus leaf pulp, respectively, while the plants with the highest antioxidant activity, flavonoid and indigestible polysaccharide contents was mangosteen fruit peel. Regular consumption of these plants may associate with reduced risks of diabetes, Alzheimer's disease and some other oxidative stress related diseases, and gain health benefit from prebiotic substances in these food plants.

\section{Acknowledgements}

The authors would like to thank the Faculty of Science, King Mongkut's Institute of Technology Ladkrabang, Thailand for financial support of this research project.

\section{References}

[1] M Blasa, L Gennari, D Angelino and P Ninfali. Fruit and Vegetable Antioxidants in Health. In: RR Watson and VR Preedy (Eds.). Bioactive Food in Promoting Health: Fruits and vegetables. Elsevier, New York, USA, 2010, p. 37-58.

[2] AM Pisoschi and A Pop. The role of antioxidants in the chemistry of oxidative stress: A review. Eur. J. Med. Chem. 2015; 97, 55-74.

[3] P Rajendran, N Nandakumar, T Rengarajan, R Palaniswami, EN Gnanadhas, U Lakshminarasaiah, J Gopas and I Nishigaki. Antioxidants and human diseases. Clin. Chim. Acta 2014; 436, 332-47.

[4] DK Patel, R Kumar, D Laloo and S Hemalatha. Diabetes mellitus: An overview on its pharmacological aspects and reported medicinal plants having antidiabetic activity. Asian Pac. J. Trop. Biomed. 2012; 2, 411-20.

[5] P Arulselvan, HAA Ghofar, G Karthivashan, MFA Halim, MSA Ghafar and S Fakurazi. Antidiabetic therapeutics from natural source: A systematic review. Biomed. Prev. Nutr. 2014; 4, 607-17.

[6] M Heinrich and HL Teoh. Galanthamine from snowdrop-the development of a modern drug against Alzheimer's disease from local Caucasian knowledge. J. Ethnopharmacol. 2004; 92, 147-62.

[7] N Tabet. Acetylcholinesterase inhibitors for Alzheimer's disease: Anti-inflammatories in acetylcholine clothing! Age. Ageing 2006; 35, 336-8.

[8] H Sugimoto. The new approach in development of anti-Alzheimer's disease drugs via the cholinergic hypothesis. Chem. Biol. Interact. 2008; 175, 204-8.

[9] DA Butterfield, A Castegna, CB Pocernich, J Drake, G Scapagnini and V Calabrese. Nutritional approaches to combat oxidative stress in Alzheimer's disease. J. Nutr. Biochem. 2002; 13, 444-61.

[10] P Maisuthisakul, S Pasuk and P Ritthiruangdej. Relationship between antioxidant properties and chemical composition of some Thai plants. J. Food Compos. Anal. 2008; 21, 229-40.

[11] J Kubola, S Siriamornpun and N Meeso. Phytochemicals, vitamin C and sugar content of Thai wild fruits. Food Chem. 2011; 126, 972-81.

[12] S Nanasombat, T Bubpasawan, N Tamaput and Y Srimakhan. Antimicrobial activity of Thai medicinal plants against beverage spoilage microorganisms and their potential in retarding Alzheimer's disease progression. Pharmacog. Commun. 2014; 4, 77-87.

[13] K Sadabpod, K Kangsadalampai and L Tongyonk. Antioxidant activity and antimutagenicity of Hom Nil rice and black glutinous rice. J. Health Res. 2010; 24, 49-54. 
http://wjst.wu.ac.th

[14] W Pothirat, MT Chomnawang, R Supabphol and W Gritsanapan. Comparison of bioactive compounds content, free radical scavenging and anti-acne inducing bacteria activities of extracts from the mangosteen fruit rind at two stage of maturity. Fitoterapia 2009; 80, 442-7.

[15] P Sithisarn and S Jarikasem. Antioxidant activity of Acanthopanax trifoliatus. Med. Princ. Pract. 2009; 18, 393-8.

[16] O Neamsuvan, N Madeebing, L Mah and W Lateh. A survey of medicinal plants for diabetes treating from Chana and Nathawee district, Songkhla province, Thailand. J. Ethnopharmacol. 2015; 174; 82-90.

[17] K Ingkaninan, P Temkitthawon, K Chuenchom, T Yuyaem and W Thongnoi. Screening for acetycholinesterase inhibitory activity in plants used in Thai traditional rejuvenating and neurotonic remedies. J. Ethnopharmacol. 2003; 89, 261-4.

[18] P Tappayuthpijarn, A Itharat and S Makchuchit. Acetylcholinesterase inhibitory activity of Thai traditional nootropic remedy and its herbal ingredients. J. Med. Assoc. Thai. 2011; 94, S183-9.

[19] M Bahmani, H Golshahi, K Saki, M Rafieian-Kopaei, B Delfan and T Mohammadi. Medicinal plants and secondary metabolites for diabetes mellitus control. Asian Pac. J. Trop. Disease. 2014; 4, S687-92.

[20] D Mudgil and S Barak. Composition, properties and health benefits of indigestible carbohydrate polymers as dietary fiber: A review. Int. J. Biol. Macromol. 2013; 61, 1-6.

[21] JG Muir, SJ Shepherd, O Rosella, R Rose, JS Barrett and PR Gibson. Fructan and free fructose content of common Australian vegetables and fruits. J. Agr. Food Chem. 2007; 55, 6619-27.

[22] P Thammarutwasik, T Hongpattarakere, S Chantachum, K Kijroongrojana, A Itharat, W Reanmongkol, S Tewtrakul and B Ooraikul. Prebiotics: A review. Songklanakarin J. Sci. Tech. 2009; 31, 401-8.

[23] AY Koka, FL Beltrame and AV Pereira. Several aspects of Zingiber zerumbet: A review. Rev. Bras. Farmacogn. 2016; 26, 385-91.

[24] S Sancheti, S Sancheti and SY Seo. Antidiabetic and antiacetylcholinesterase effects of ethyl acetate fraction of Chaenomeles sinensis (Thouin) Koehne fruits in streptozotocin-induced diabetic rats. Exp. Toxicol. Pathol. 2013; 65, 55-60.

[25] MR Loizzo, AM Saab, R Tundis, F Menichini, M Bonesi, V Piccolo, GA Statti, BD Cindio, PJ Houghton and $\mathrm{F}$ Menichini. In vitro inhibitory activities of plants used in Lebanon traditional medicine against angiotensin converting enzyme (ACE) and digestive enzymes related to diabetes. J. Ethnopharmacol. 2008; 119, 109-16.

[26] GN Kim, JG Shin and HD Jang. Antioxidant and antidiabetic activity of Dangyuja (Citrus grandis Osbeck) extract treated with Aspergillus saitoi. Food Chem. 2009; 117, 35-41.

[27] W Brand-Williams, ME Cuvelier and C Berset. Use of a free radical method to evaluate antioxidant activity. LWT Food Sci. Tech. 1995; 28, 25-30.

[28] C Lado, M Then, I Varga, E Szoke and K Szentmihályi. Antioxidant property of volatile oils determined by the ferric reducing ability. Z. Naturforsch. C 2004; 59, 354-8.

[29] GL Ellman, KD Courtney, VJ Andres and RM Featherstone. A new rapid colorimetric determination of acetylcholinesterase activity. Biochem. Pharmacol. 1961; 7, 88-95.

[30] S Sancheti, S Sancheti, BH Um and SY Seo. 1,2,3,4,6-penta-O-galloyl- $\beta$-D-glucose: A cholinesterase inhibitor from Terminalia chebula. South Afr. J. Bot. 2010; 76, 285-8.

[31] VL Singleton, R Orthofer and RM Lamuela-Raventós. Analysis of total phenols and other oxidation substrates and antioxidants by means of Folin-Ciocateu reagent. Meth. Enzymol. 1999; 299, 152-78.

[32] A Kathirvel and V Sujatha. In vitro assessment of antioxidant and antibacterial properties of Terminalia chebula Retz. leaves. Asian Pac. J. Trop. Biomed. 2012; 2, S788-95.

[33] S Wichienchot, P Thammarutwasik, A Jongjareonrak, W Chansuwan, P Hmadhlu, T Hongpattarakere, A Itharat and B Ooraikul. Extraction and analysis of prebiotics from selected plants from southern Thailand. Songklanakarin J. Sci. Tech. 2011; 33, 517-23.

[34] GL Miller. Use of dinitrosalicylic acid reagent for determination of reducing sugar. Anal. Chem. $1959 ; \mathbf{3 1}, 426-8$. 
http://wjst.wu.ac.th

[35] M Dubois, KA Gilles, JK Hamilton, PA Rebers and F Smith. Colorimetric method for determination of sugars and related substances. Anal. Chem. 1956; 28, 350-6.

[36] R Agil, A Gaget, J Gliwa, TJ Avis,WG Willmore and F Hosseinian. Lentils enhance probiotic growth in yogurt and provide added benefit of antioxidant protection. LWT Food Sci. Tech. 2013; 50, 45-9.

[37] AOAC. Official Methods of Analysis: AOAC Official Method. Association of Official Chemists, Washington DC, USA, 2005.

[38] P Boonsong, N Laohakunjit and O Kerdchoechuen. Identification of polyphenolic compounds and colorants from Tiliacora triandra (Diels) leaves. Agr. Sci. J. 2009; 40, $13-16$.

[39] M Vessal, M Hemmati and M Vasei. Antidiabetic effects of quercetin in streptozocin-induced diabetic rats. Comp. Biochem. Physiol. Part C: Toxicol. Pharmacol. 2003; 135, 357-64.

[40] A Eidi, M Eidi and E Esmaeili. Antidiabetic effect of garlic (Allium sativum L.) in normal and streptozotocin-induced diabetic rats. Phytomedicine 2006; 13, 624-9.

[41] G Saravanan, P Ponmurugan, GPS Kumar and T Rajarajan. Antidiabetic properties of $S$-allyl cysteine, a garlic component on streptozotocin-induced diabetes in rats. J. Appl. Biomed. 2009; 7, 151-9.

[42] K Shimizu, M Ozeki, A Iino, S Nakajyo, N Urakawa and M Atsuchi. Structure-activity relationships of triterpenoid derivatives extracted from Gymnema inodorum leaves on glucose absorption. Jpn. J. Pharmacol. 2001; 86, 223-9.

[43] A Chiabchalard, T Tencomnao and R Santiyanont. Effect of Gymnema inodorum on postprandial peak plasma glucose levels in healthy human. Afr. J. Biotechnol. 2010; 9, 1079-85.

[44] Z Yang, Y Wang, Y Wang and Y Zhang. Bioassay-guided screening and isolation of $\alpha$-glucosidase and tyrosinase inhibitors from leaves of Morus alba. Food Chem. 2012; 131, 617-25.

[45] C Liu,W Xiang, Y Yu, ZQ Shi, XZ Huang and L Xu. Comparative analysis of 1-deoxynojirimycin contribution degree to $\alpha$-glucosidase inhibitory activity and physiological distribution in Morus alba L. Ind. Crop. Prod. 2015; 70, 309-15.

[46] Y Jiao, X Wang, X Jiang, F Kong, S Wang and C Yan. Antidiabetic effects of Morus alba fruit polysaccharides on high-fat diet-and streptozotocin-induced type 2 diabetic rats. J. Ethnopharmacol. 2017; 199, 119-27.

[47] Y Zhang, C Ren, G Lu, W Cui, Z Mu, H Gao and Y Wang. Purification, characterization and antidiabetic activity of a polysaccharide from mulberry leaf. Regul. Toxicol. Pharm. 2014; 70, 687-95.

[48] W Luo, M Zhao, B Yang, J Ren, G Shen and G Rao. Antioxidant and antiproliferative capacities of phenolics purified from Phyllanthus emblica L. fruit. Food Chem. 2011; 126, 277-82.

[49] R Zadernowski, S Czaplicki and M Naczk. Phenolic acid profiles of mangosteen fruits (Garcinia mangostana). Food Chem. 2009; 112, 685-9.

[50] HM Kredy, D Huang, B Xie, H He, E Yang, B Tian and D Xiao. Flavonols of lotus (Nelumbo nucifera, Gaertn.) seed epicarp and their antioxidant potential. Eur. Food Res. Tech. 2010; 231, 38794.

[51] GC Yen, PD Duh and HJ Su. Antioxidant properties of lotus seed and its effect on DNA damage in human lymphocytes. Food Chem. 2005; 89, 379-85.

[52] A Somanabandhu, N Ruangrungsi, GL Lange and MG Organ. Constituents of the stem bark of Zanthoxylum limonella. J. Sci. Soc. Thailand 1992; 18, 181-5.

[53] NT Phuong, KA Lee, SJ Jeong, CX Fu, JK Choi, YH Kim and JS Kang. Capillary electrophoretic method for the determination of diterpenoid isomers in Acanthopanax species. J. Pharm. Biomed. Anal. 2006; 40, 56-61.

[54] P Sithisarn, S Jarikasem and K Thisayakorn. Acanthopanax trifoliatus, a Potential Adaptogenic Thai Vegetable for Health Supplement. In: I Rasooli (Ed.). Phytochemicals-Bioactivities and Impact on Health. Intech, Rijeka, Croatia, 2011, p. 253-68.

[55] J Tangjitjaroenkun, O Chantarasriwong and $\mathrm{W}$ Chavasiri. Chemical constituents of the stems of Zanthoxylum limonella Alston. Phytochem. Lett. 2012; 5, 443-5.

[56] JF Morton. Chrysophyllum cainito L. Sapotaceae. In: JF Morton (Ed.). Fruit of Warm Climates. Creative Resource Systems, Miami, USA, 1987, p. 408-10. 
http://wjst.wu.ac.th

[57] T Seal. Evaluation of nutritional potential of wild edible plants, traditionally used by the tribal people of Meghalaya state in India. Am. J. Plants Nutr. Fertilization Tech. 2012; 2, 19-26.

[58] R Bawankar, VC Deepti, P Singh, R Subashkumar, G Vivekanandhan and S Babu. Evaluation of bioactive potential of an Aloe vera sterol extract. Phytother. Res. 2013; 27, 864-8.

[59] ES Kim, JB Weon, BR Yun, J Lee, MR Eom, KH Oh and CJ Ma. Cognitive enhancing and neuroprotective effect of the embryo of the Nelumbo nucifera seed. Evid. Based Compl. Alternat. Med. 2014; 2014, 869831.

[60] M Mehta, A Adem and M Sabbagh. New acetylcholinesterase inhibitors for Alzheimer's disease. Int. J. Alzheimer's Disease 2012; 2012, 728983.

[61] SH Al-Sheraji, A Ismail, MY Manap, S Mustafa, RM Yusof and FA Hassan. Prebiotics as functional foods: A review. J. Funct. Food. 2013; 5, 1542-53.

[62] Y Zhang, H Zeng, Y Wang, S Zeng and B Zheng. Structural characteristics and crystalline properties of lotus seed resistant starch and its prebiotic effects. Food Chem. 2014, 155, 311-8.

[63] D Sumczynski, Z Bubelová and M Fišera. Determination of chemical, insoluble dietary fibre, neutral-detergent fibre and in vitro digestibility in rice types commercialized in Czech markets. $J$ Food Compos. Anal. 2015; 40, 8-13.

[64] P Hołownia, B Jaworska-Łuczak, I Wiśniewska, P Biliński and A Wojtyła. The benefits \& potential health hazards posed by the prebiotic inulin: A review. Polish J. Food Nutr. Sci. 2010; 60, 201-11.

[65] N Vatanasuchart, B Niyomwit and $\mathrm{K}$ Wongkrajang. Resistant starch content, in vitro starch digestibility and physico-chemical properties of flour and starch from Thai bananas. Maejo Int. J. Sci. Tech. 2012; 6, 259-71.

[66] J van Loo, P Coussement, LD Leenheer, H Hoebregs and G Smits. On the presence of inulin and oligofructose as natural ingredients in the western diet. Crit. Rev. Food Sci. Nutr. 1995; 35, 525-52. 